\title{
The Beginnings of an Empire. The Transformation of the Ottoman State into an Empire, demonstrated at the example of Grand Vizier Mahmud Pasha's life and accomplishments
}

\author{
Vera Flatz \\ Kerngebiet: Neuzeit \\ eingereicht bei: Yasir Yilmaz, MA PhD und Univ.-Prof. Dr. Stefan Ehrenpreis \\ eingereicht im: WiSe 2019/20 \\ Rubrik: Seminar-Arbeit
}

\begin{abstract}
The Beginnings of an Empire. The Transformation of the Ottoman State into an Empire, demonstrated at the example of Grand Vizier Mahmud Pasha's life and accomplishments

The following seminar paper deals with Grand Vizier Mahmud Pasha's life and the processes that turned an Ottoman principality into the Ottoman Empire. Starting with Sultan Mehmed's II appointment in 1444, important practices such as the nomination of a grand vizier changed significantly. Moreover, Mehmed II built a new palace which reflected the new imperial self-perception, a new code of law was installed, and the empire was centralised. All these developments become especially visible in the life of Grand Vizier Mahmud Pasha Angelovic. The paper examines secondary literature as well as contemporary sources of Kritobolous and Ibn Khaldun. Sources on Mahmud Pasha's life are rare and need to be analysed with caution as his posthumous legend influenced the production of literature about his life.
\end{abstract}

\section{Introduction}

Mahmud Pasha Angelovic, born at the beginning of the $15^{\text {th }}$ century in a town in Serbia, became one of the most influential grand viziers of the Ottoman Empire. How did that happen? In 1453, Mehmed II conquered Constantinople and made it the capital of one of the biggest empires of the early modern period. Mahmud Pasha became his second grand vizier and contributed significantly to the rise of the Ottoman Empire. 
Characteristic for that period is the immense change the Ottoman state underwent, from a tribal society into a global empire. This change was reflected in virtually every aspect of Ottoman rule. This paper will therefore aim at answering the question: How was the Ottoman state transformed into an empire, and how is that transformation reflected in Mahmud Pasha's life? It will be argued that Mahmud Pasha's rule reflects major changes that happened after the conquest of Constantinople. His person exemplifies the changes in the selection of high officials in court, the palace as the next centre of power, the increasing power of the grand vizier, the renewed imperial picture of the sultan, the recent conflict structures, the new code of law and the changes in architecture, art, and literature. Most importantly, it reflects the centralisation of the new empire.

The main monograph that will be used for this paper is "The Sultan of Vezirs"1 by Theoharis Stavrides. He collected all available sources on Mahmud Pasha's life and put them into context with contemporary developments. Other works that will be used to expand the research include "The Ottoman Empire. The Classical Age 1300-1600"2 by HaIil Inalcık, "Architecture, Ceremonial, and Power. The Topkapi Palace in the Fifteenth and Sixteenth Centuries" ${ }^{\prime 3}$ by Gülru Necipoğlu and several academic articles. Furthermore, contemporary sources of Kritobolous ${ }^{4}$, edited by Diether Reinsch, and Ibn Khaldun ${ }^{5}$ will be used. Unfortunately, sources on Mahmud Pasha are scarce and many details of his life are unknown. The sources which exist have to be analysed with care as his posthumous legend influenced the production of literature about his life.

In the first part of the paper, Mahmud Pasha's childhood and origins will be explained. Linked to this is the practice of devshirme, which completely changed the process of appointing important figures at court. In the second part, several changes under the rule of Mehmed II which were linked to Mahmud Pasha will be analysed. This includes the fall of Constantinople, the palace as the new centre of the empire, the new code of law and the renewed image of the sultan. Finally, a closer look will be taken at the development of the office of grand vizier and how it changed during the reign of Mehmed II.

\section{Mahmud Pasha's Origins and Devshirme}

Most scholars agree that Mahmud Pasha Angelovic was born in Serbia, in the village of Novo Brdo. Other Ottoman academics, however, provide different information, some claiming that Mahmud Pasha was born in Croatia. Nevertheless, the theory that he originated from Serbia is the most verisimilar one also because Serbia is named in the most plausible sources, including Ibn Kemal's writings. ${ }^{6}$ Moreover, his family back-

1 Theoharis Stavrides, The Sultan of Vezirs. The Life and Times of the Ottoman Grand Vezir Mahmud Pasha Angelovic (1453-1474), Leiden-Boston-Köln 2001.

2 Halil Inalcık, The Ottoman Empire. The Classical Age 1300-1600, London 1973.

3 Gülru Necipoğlu, Architecture, Ceremonial, and Power. The Topkapi Palace in the Fifteenth and Sixteenth Centuries, Cambridge 1991.

4 Diether Roderich Reinsch, Mehmet II. erobert Konstantinopel. Das Geschichtswerk des Kritobulos von Imbros, Graz 1986.

$5 \quad$ Ibn Khaldun, The Muqaddimah. An Introduction to History, Princeton 1980.

6 Stavrides, The Sultan of Vezirs, pp. 73-74. 
ground is not completely clear. Although the sources again contradict each other, it is likely that Mahmud Pasha originated from two aristocratic Balkan families.?

An important practice that changed during the reign of Mehmed II is the appointment of non-Turkish people to important offices. Before his reign, bureaucratic personnel were almost exclusively native born Muslims with an ulama ${ }^{8}$ background. This practice had started already in the pre-Ottoman states and was continued until the ascendance of Mehmed II. In the $14^{\text {th }}$ century, most slaves were prisoners of war, and others came from the slave markets. At the end of the $14^{\text {th }}$ century, a new practice arose: devshirme. ${ }^{9}$ Devshirme has been defined as:

"The forcible removal, in the form of a tribute, of children of the Christian subjects from their ethnic, religious, and cultural environment and their transplantation into the Turkish-Islamic environment with the aim of employing them in the service of the Palace, the army, and the state, whereby they were on the one hand to serve the Sultan as slaves and freedmen and on the other to form the ruling class."10

The devshirme was a very harsh practice and many scholars argue that it went against the Shariah as the Islamic law forbids the forceful conversion of Christian subjects. Christians had the status of dhimmi, which is connected to the right to freely exercise their religious beliefs. ${ }^{11}$ In contrast, the government saw the devshirme practice rather as a form of levy than as an enslavement of Christians. The practice became very popular; in the $15^{\text {th }}$ and $16^{\text {th }}$ century, the majority of slaves had a devshirme background. These children were sent to Istanbul and were then separated; the most promising ones stayed in the palaces in Istanbul or Edirne and received special training. The others were trained to enter the Janissary corps. ${ }^{12}$

The change from taking personnel with an ulama background to a devshirme background had several reasons. Firstly, the $15^{\text {th }}$ century was a time of great expansion. Many regions, such as Bosnia, Serbia or Anatolia came under Ottoman rule and needed to be incorporated into the growing empire. Controlling and ruling those regions required new personnel. One of the reasons why Mehmed II favoured men from Christian backgrounds is that they originated from those regions, which would facilitate the

$7 \quad$ Stavrides, The Sultan of Vezirs, p. 75.

8 The ulama were a powerful class that determined the consensus on questions concerning the Islamic law in early Islamic times and played an important clerical role as well: Asma Afsaruddin, Ulama, in: Britannica, https://www. britannica.com/topic/ulama, accessed 30.11.2020.

$9 \quad$ Inalcık, The Ottoman Empire, p. 77.

10 Original quote: „Das Phänomen, dessen Ursprung und Wesen den Gegenstand unserer Untersuchung bilden, ist das Devshirme, d. h. die vom türkischen Staat in Form eines Tributs durchgeführte gewaltsame Abtrennung von Kinder der christlichen Untertanen aus ihrer ethnischen, religiösen und kulturellen Umgebung und ihre Verpflanzung in die türkisch-islamische zum Zweck ihrer Verwendung im Palast-, Militär- und Staatsdienst, wobei sie einerseits dem Sultan als Sklaven und Freigelassene (Klienten) dienen, andererseits die herrschende Schicht des Staate bilden sollen.": Basilike D. Papoulia, Ursprung und Wesen der Knabenlese im osmanischen Reich, München 1963, p. 1.

11 Paul Wittek, Devshirme and Sharia, in: Bulletin of the School of Oriental and African Studies 17 (1955), No. 2, pp. 271278, here p. 271.

12 Inalcık, The Ottoman Empire, pp. 78-79 
transition process. Additionally, this made him more independent from the influential Ottoman elites such as the Çandarlı family. ${ }^{13}$ Another reason for this shift was that boys with a devshirme background were completely obedient and loyal to the sultan. They could not rely on a strong family background in Istanbul or Edirne and had no networks inside the palace; therefore, they were completely dependent on the sultan. ${ }^{14}$

In the case of Mahmud Pasha Angelovic it is rather unlikely that he was part of the regular devshirme practice. Most likely he was taken by horsemen of Sultan Murad II in 1427. Mahmud Pasha presumably had an aristocratic background, and families with a high status were usually not the target of devshirme. Moreover, at that time Serbia was only partially integrated into the Ottoman Empire, which makes it even more unlikely that a normal devshirme took place there. On the other hand, Mahmud Pasha was taken on the way from one city to another, seemingly a coincidence. This could point to Mahmud Pasha being a prisoner of war. The sources do not clearly indicate whether it was a raid taking children of conquered aristocratic Byzantine and Balkan families to the palace to train them for the highest offices, or if it was a mere coincidence that Mahmud Pasha was taken. ${ }^{15}$

Interestingly, the identity-building process of the Ottoman Empire facilitated the transformation process as well. In contrast to the nation-building of the $19^{\text {th }}$ and $20^{\text {th }}$ century, the Ottoman identity was rather fluid, flexible and tried to incorporate as many people as possible. It was more an addition of a new identity than an exchange for the old one. This allowed for a much more effective and positive rule in the conquered territories, as the new elites could still use their old networks to rule the territories. ${ }^{16} \mathrm{How}$ ever, these men of the new elite needed to be extremely loyal and devoted Ottomans and Muslims. Evidence that supports the claim that the devshirme practice contributed to a more rapid Islamisation in the conquered territories can also be found in Bosnia. Sanja Kadric argues that the devshirme practice in Bosnia, which started very soon after the occupation, contributed to the rapid Islamisation there. There are numerous records which show that palace personnel of devshirme origin brought converted family members into the palace, or the family members were rewarded a $\operatorname{timar}^{17} .^{18}$

These beneficial family ties are visible in Mahmud Pasha's case as well. Mahmud Pasha's brother Michael Angelovic was a high official in the fealty of Despot George Brankovic. After Brankovic's death and the ascendance of his son Lazar, Michael Angelovic mediated a peace between Serbia and the Ottomans. It is widely believed that Mahmud Pasha was the mediator on the side of the Ottomans. ${ }^{19}$ After Lazar's death, Michael

13 Christine Isom-Verhaaren, Constructing Ottoman Identity in the Reigns of Mehmed II and Bayezid II, in: Journal of the Ottoman and Turkish Studies Association 1 (2014), No. 1-2, pp. 111-128, here p. 113.

14 Inalcık, The Ottoman Empire, p. 79.

15 Stravides, The Sultan of Vezirs, pp. 107-109.

16 Isom-Verhaaren, Constructing Ottoman Identity, p. 112.

17 Because of a shortage of coins, the large standing army could not be paid a salary in cash. It became the practice to award them agricultural land to pay them: Halil Inalcık, The Ottoman Empire, p. 107.

18 Sanja Kadric, The Islamisation of Ottoman Bosnia. Myths and Matters, in: Andrew C. S. Peacock (Ed.), Islamisation. Comparative Perspectives from History, Edinburgh 2017, pp. 277-295, here pp. 286-287. 
Angelovic became part of the regency and got the most important position, the great voivode, partly because of his family ties to the Ottoman court. He was therefore also a representative for the pro-Ottoman side. ${ }^{20}$ Michael was later arrested and stayed in captivity for more than two years even though his brother tried to intervene. Most likely, Michael Angelovic ended up at the Ottoman court. He remained a Christian but was held in high esteem at the court or even held a high office. ${ }^{21}$ Mahmud Pasha's mother lived at the end of her life in Istanbul as well and had remained a Christian like her son Michael. ${ }^{22}$ Because of these family ties, Mahmud Pasha was an extremely valuable asset for the sultan. Mahmud Pasha used his family connections but also his own diplomatic skills to integrate newly conquered territories into the Ottoman Empire. He contributed to the surrenders of Smederevo, Trabzon, Mytilene and the Peloponnese.23

During the reign of Mehmed II, most of the higher positions in court were given to men from a devshirme background or to children from aristocratic families in the conquered territories. This was done to ensure absolute loyalty from the converted boys and to be independent from the influence of other Ottoman aristocratic families. Besides, the family background of these men helped to influence the integration and Islamisation of the new territories.

\section{Mahmud Pasha's Rise and Changes in the Ottoman Empire}

In this chapter several changes during the reign of Mehmed II will be analysed. They will also be brought into connection with Grand Vizier Mahmud Pasha, who was appointed to that position in 1456. Many of these changes contributed to the transformation of a principality into the centralised Ottoman Empire.

\subsection{The Fall of Constantinople}

The first time Mahmud Pasha appears in the sources is during the siege of Constantinople. The Greek historian Kritobolous is the only one who mentions Mahmud Pasha this early. He discusses him first when he talks about the composition of the army.

"He [Sultan Mehmed] gave Ishak, who then was the beylerbey of Asia, and Mahmud, Comes at that time, brave men, who were admired because of their war experience and boldness, the part from the Myriandrion to the Golden Gate and the sea there."24

20 Milos Ivanovic, The Nobility of the Despotate of Serbia between Ottoman Empire and Hungary (1457-1459), in: Kosana Jovanovic/Suzana Miljan (Eds.), Secular Power and Sacral Authority in Medieval East-Central Europe, Amsterdam 2018, pp. 167-177, here p. 170.

21 Stavrides, The Sultan of Vezirs, p. 99.

22 Ibid., p. 93.

23 Isom-Verhaaren, Constructing Ottoman Identity, p. 115.

24 Original quote: „Ishak aber, der damals Statthalter von Asien war, und Mahmut, zu jener Zeit Komes, tapferen Männern, die wegen ihrer Kriegserfahrung und Kühnheit viel bewundert wurden, übergab er den vom Myriandrion bis zum Goldenen Tor und zum dortigen Meer reichenden Abschnitt.": Roderich Reinsch, Mehmet II. erobert Konstantinopel, p. 81 
Kritobolous describes Mahmud Pasha as a courageous man who was important for the conquest of Constantinople. Mahmud Pasha appears frequently throughout the book and is portrayed as succeeding in one of the most difficult and most important parts of the siege. ${ }^{25}$ Stavrides points out that the fact that Mahmud Pasha was fighting alongside the Beylerbey of Anatolia and was called Comes by Kritobolous indicates that he already held an important position at the Ottoman court at that time. Interestingly, Kritobolous is the only contemporary author who indicates that Mahmud Pasha was part of the siege of Constantinople. This could be due to the fact that by the time Kritobolous wrote his work, Mahmud Pasha had already been appointed as grand vizier. Therefore, the heroic descriptions could be seen as flattery and the attempt of Kritobolous to be recognised by the court. On the other hand, Kritobolous was the only author who showed the Ottoman side of the conquest; therefore, it is not surprising that Mahmud Pasha does not occur in other Greek sources. ${ }^{26}$

In general, the fall of Constantinople can be called a turning point in history for the Ottomans as well as for the Western world. Franz Babinger points out that Constantinople was more significant than whole countries. In a city where the leader of Eastern Christendom had reigned since the $4^{\text {th }}$ century, the archenemies of the Christian church were now the new leaders. The effect on many Western powers was immense, and especially pope Nicholas $V$ and his cardinals were shocked; however, the Western powers were occupied with their own quarrels and few forces were sent to help the Byzantine Empire. ${ }^{27}$ From that moment on, the Ottomans were seen as the classic "Other" described in Edward Said's Orientalism. Islam, and with it the Ottoman Empire, represented a constant danger for Christianity and the Western world. Ottomans were seen as barbaric, dark creatures, and Christian authors had little interest in learning about the high culture of the Ottoman court. To this day, originating from the time of Mehmed II and the formation of the empire, Islam is very often associated with terror, devastation and barbaric people. ${ }^{28}$

Kritobolous describes the fall of Constantinople very detailed as well. He depicts the siege, the battle and the time afterwards as very brutal and merciless. According to his account women and children were murdered, young Byzantine women were raped, nuns were killed, and churches were robbed. ${ }^{29}$ Not without reason, this event is often taken as a partition between the middle ages and the early modern age. It marked the end of the Eastern Roman Empire, the triumph of modern weapons, especially the cannon, and it started the period of an increased Ottoman presence in Europe. ${ }^{30}$

Another event connected to the fall of Constantinople that holds importance for Mahmud Pasha is the dismissal of Grand Vizier Çandarlı Halil. Çandarlı Halil Pasha had been an adversary of Mehmed II for a long time. In 1446 he organised a Janissary revolt

25 Reinsch, Mehmed II. erobert Istanbul, p. 111

26 Stavrides, The Sultan of Vezirs, pp. 112-113.

27 Franz Babinger, Mehmed the Conqueror and his Time, Princeton 1953, p. 98.

28 Edward Said, Orientalism. Western Conceptions of the Orient, London 1978, p. 59.

29 Reinsch, Mehmed II. erobert Istanbul, pp. 120-121.

30 Inalcık, The Ottoman Empire, p. 26. 
against Mehmed II and forced him to give his throne back to his father Murad II. When Murad II died, Mehmed could ascend to the throne once more. ${ }^{31}$ After the fall of Constantinople Mehmed was strong enough to imprison Çandarlı Halil Pasha, who was executed after forty days of imprisonment. He had been accused of working with the Greeks and taking bribes from them. ${ }^{32}$ Kritobolous reflects that event as well, writing about the torture of the former grand vizier and recounting his immense wealth which was found after his death. ${ }^{33}$ With the death of Çandarlı Halil Pasha, the Çandarlı family lost their power, after four family members had served as grand viziers consecutively. ${ }^{34}$ Some sources claim that Mahmud Pasha was installed as grand vizier right after Halil Pasha. It is however more likely that Mahmud Pasha was appointed as vizier in 1454 and as grand vizier in $1456 .{ }^{35}$

The conquest of Constantinople held immense importance for Ottoman as well as European history. It marked the transition from a principality to an empire and gave Mehmed II the byname "the Conqueror". Until today, the fall of Constantinople is taken as a date for the beginning of the Modern Period. Furthermore, the origins, the importance and often also the end of a grand vizier's life changed significantly afterwards.

\subsection{The Palace as the new Centre of the Empire}

After the conquest of Istanbul, Mehmed needed a palace which could mirror his claim to the throne. Immediately after the conquest he ordered the construction of a new palace on the site of the Forum Tauri, which was completed in 1455. Shortly afterwards, however, the sultan ordered the construction of another new palace in 1459, known today as the Topkapi Palace. There has been an ongoing debate why Mehmed felt the need for a new palace so soon after the first one was built. ${ }^{36}$ Inalcik attributes this to Mehmed feeling insecure in the midst of the city. ${ }^{37}$ Others claim it was due to the fact that the old palace was not big enough, or that he did not feel safe and was eager to build a stronger fortress. All of these reasons might have been factors, but the most important factor was the new imperial image that Mehmed II wanted to present. ${ }^{38}$ Mehmed saw himself as the heir to the Byzantine Empire, and therefore the Eastern Roman Empire. Constantinople, now Istanbul, lay at the borders of Europe and it inspired the dream of controlling parts of Europe as well. Western powers were convinced that Mehmed would invade Italy and the dream of world domination seemed possible during his reign. These imperial claims needed to be reflected by the new palace. ${ }^{39}$ The old one had been big enough to accommodate the palace personnel as well, but it did not satisfy the sultan's wish for grandeur. Also, the new location in the neighbourhood

31 Inalcık, The Ottoman Empire, p. 21.

32 Babinger, Mehmed the Conqueror and his Time, p. 102.

33 Reinsch, Mehmed II. erobert Istanbul, p. 140.

34 Babinger, Mehmed the Conqueror and his Time, p. 102.

35 Stavrides, The Sultan of Vezirs, pp. 59-61.

36 Inalcık, The Ottoman Empire, p. 76.

37 Ibid

38 Necipoğlu, Architecture, Ceremonial, and Power, p. 10.

39 Ibid., pp. 10-11. 
of the two magnificent buildings the Hagia Sophia and the Hippodrome reflected the imperial claim. The Hagia Sophia had already been transformed into a mosque and the Hippodrome was used for Ottoman festivities. The exact placement meant that Mehmed had a view over the sea, which contemporaries saw as a metaphor for his dominion over both the Black Sea and the Mediterranean. ${ }^{40}$

At the same time, not only the outside of the palace sent the message of imperial sovereignty, but the palace became the political centre of the empire as well. By appointing boys of a devshirme background to the most important offices in the empire, the dominant families, within the central political sphere as well as the rural, lost their power. This was done to prevent alternative power accumulations elsewhere in the vast empire. The power was now accumulated at court. The men who graduated from the palace education built their own networks and offered lower positions to their allies. Given time, the local elites were replaced by palace graduates who had a strong connection to the court in Istanbul. This produced a network of relationships throughout the empire, which was centred at the palace in Istanbul. ${ }^{41}$

Another point that is connected to the architecture of the palace is the withdrawal of the sultan. In general, the new palace was built at the city's borders, secluded from the public eye. ${ }^{42}$ Moreover, "the three courts of the palace were arranged successively, with access to the person of the sultan as their basic criterion."43 The sultan spent most of his time in the Inner Palace, where the harem and other apartments were situated. The Second court, adjoining the Inner Palace, held the services and organisations which were responsible for the connection to the outer world. Between the two courts was the Gate of Felicity, which marked a sharp border where only the highest officials could enter, including the grand vizier. ${ }^{44}$ While security issues might have played a role as well, the major reason for this withdrawal was the new idea of royal seclusion and sultanic sacredness. The idea behind it was that the sultan, "this spiritual being, endowed with divine light" ${ }^{\prime 45}$ could not be present at the same places as ordinary people. ${ }^{46}$ Closely connected to the imperial seclusion is the new dynastic law code kanunname, which records this practice.

\subsection{The Kanunname and the New Image of the Sultan}

Kanun is, opposed to the religious law, the regulation which was determined by the sultan alone. The kanuns mostly affected the administration and the public sphere. The practice of kanun started in the mid eleventh century with the beginning of Turkish rule, as establishing royal code of laws had already been common in Turkish tradition. ${ }^{47}$

40 Necipoğlu, Architecture, Ceremonial, and Power, p. 13.

41 Baki Tezkan, The Second Ottoman Empire. The Political and Social Transformation in the Early Modern World, Cambridge 2010, pp. 93-94.

42 Necipoğlu, Architecture, Ceremonial, and Power, p. 16.

43 Stavrides, The Sultan of Vezirs, p. 30

44 Inalcık, The Ottoman Empire, p. 77.

45 Necipoğlu, Architecture, Ceremonial, and Power, p. 16.

46 Ibid

47 Inalcık, The Ottoman Empire, p. 70. 
Mehmed II published his own code of law, called kanunname, towards the end of his reign, sometime between 1477 and 1481 . His code of law holds special importance as it is commonly regarded as the first attempt "to set out the hierarchical rules related to the appointment and promotion of officials and servants as well as fixing their place in official court protocol." ${ }^{48}$ It is important to notice that the code of law contains rules of former sovereigns as well and should therefore not be regarded as the start of a new practice but rather as the culmination of a trend. ${ }^{49}$ According to the introduction of the Nişancı Leyszade, the kanunname was written after the conquest of Istanbul, for the new empire could no longer rely on the oral traditions of its ancestors, but needed a written code of law which had symbolic and practical reasons. On the symbolic level, it signified the transformation from a tribal illiterate society into a literate empire. On the practical level, it set out the hierarchy of the palace. ${ }^{50}$

The kanunname is composed of a preamble and three parts. The preamble starts with: "This law code is my ancestor's law. It is my law too. Let my noble progeny, generation after generation act with it." ${ }^{11}$ In the first part of the kanunname the hierarchy of the Ottoman Empire is established, and the ranks of all officials are listed and described. In the second part the order of the palace, the administration and the ceremonies are characterised. Finally, the third section describes how much high officials should earn and which exact titles they should use.52 One important part of the kanunname deals with fratricide. One reason why the Ottoman Empire existed for such an extended amount of time and never fell apart was that the rulers always arranged their succession and eliminated possible inner familiar threats to the throne. ${ }^{53}$ The kannuname says that, "For the welfare of the state, the one of my sons to whom God grants the sultanate may lawfully put his brothers to death. A majority of the ulema considers this permissible." ${ }^{14}$ Mehmed II acted on this notion when he had his half-brother Ahmed executed upon his accession. ${ }^{55}$

Another very important fact that is connected to the kanunname is the theme of princely seclusion. This has already been mentioned in the previous chapter. The architecture of the palace and the new code of law go hand in hand when defining the new image of the sultan. Before Mehmed's reign public appearances of the sultan were the norm and private ones the exception. When Mehmed ascended to the throne, he continued this practice at first, also to avoid speculations about a possible death. During his reign however, the sultan increasingly withdrew from the public. Around 1475, he stopped personally presiding over the meetings of the imperial council. The kanunname sanctions this behaviour and only calls for two appearances per year when

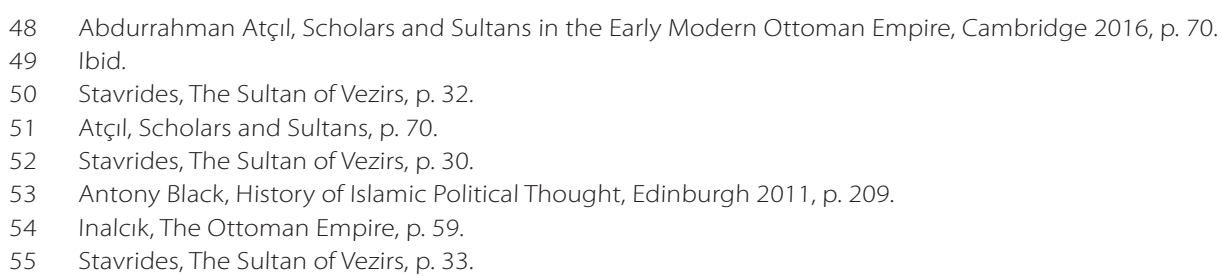


the officials had to kiss his hand. ${ }^{56} \mathrm{His}$ absence is again mirrored in the architecture of the palace. Between the second court, where the officials of the centralised government worked and the third court, where the sultan spent the majority of his time, there was an immense gate, which symbolised his supreme authority as well as the absence of the ruler. ${ }^{57}$ The Ottomans lacked a long genealogy to legitimise their rule. To compensate this, they focused primarily on the secular law. Administering justice, based on kanuns, was the key concept of the Ottoman dynasty. ${ }^{58}$ This is again a sign of the progressing centralisation of the state.

In general, the kanunname therefore reflects the centralising tendencies of the new empire as well as the new image of the sultan. Mehmed II began to withdraw from the public as well as from the administration of the state. This behaviour was sanctioned by the kanunname and was reflected in the architecture of the palace. The administrative power which the sultan gave away was directly transferred to the grand vizier. With a changing image of the sultan it is vital to look at the changing role of the grand vizier as well. This changing role of the grand vizier becomes most obvious in the figure of Mahmud Pasha Angelovic.

\section{Mahmud Pasha and the new Image of the Grand Vizier}

The office of grand vizier was not an invention of the Ottomans but had existed in earlier Islamic states as well. Stavrides argues that the first grand vizier was appointed under the Abbasids and that the office underwent considerable transformation since then. ${ }^{59}$ Ibn Khaldun mentions that already during the Umayyad dynasty the office of wazir was the highest rank in the administration. He also states that in early Islamic states an administration and therefore a grand vizier was not needed as the caliphate was mostly a religious realm and not a political one. ${ }^{60}$ However, this has been disproved by most modern scholars. Already the prophet Muhammed acted as the political leader of a new and emerging Islamic community. While he was mostly a religious leader in Mecca, he became a political statesman in Medina who tried to organise the lives of Meccan emigrants and allies of the new religion. ${ }^{61} \mathrm{Ibn}$ Khaldun also states that most of the people were illiterates and that a central administration did not exist either. He also places a more powerful and important vizierate at the beginning of the Abbasid dynasty. ${ }^{62}$ The lack of a central administration therefore plays a much more important role in the development of the office of grand vizier than the political form of the state. This development is closely connected to the centralising tendencies of the Abbasids. The administration and the reign became more tightly organised and the state suddenly became visible in the provinces because of tax collection, among other things. Never-

Stavrides, The Sultan of Vezirs, pp. 34-35.

Necipoğlu, Architecture, Ceremonial, and Power, p. 56.

Ibid., p. 57.

Stavrides, The Sultan of Vezirs, p. 37.

Ibn Khaldun, The Muqaddimah, p. 8.

Monika Tworuschka, Grundwissen Islam, Münster 2016, p. 29.

Ibn Khaldun, The Muqaddimah, p. 8. 
theless, the provinces still had different coins, weights and units of measure, different tax collection practices and the local elites remained in place. ${ }^{63} \mathrm{Ibn}$ Khaldun states that during the Abbasid dynasty, the vizier now had to oversee the tax collection process and was entrusted with the official correspondence of the caliph. ${ }^{64}$ The beginning centralisation and related tasks can therefore be seen as one of the main reasons why a more powerful vizier in the administration was needed. This is also one of the reasons why the office of grand vizier changed significantly again after the fall of Constantinople and the centralisation efforts of Mehmed II.

Mahmud Pasha Angelovic serves as the perfect example for these changes. It is not clear whether he was taken during a typical devshirme; however, he was certainly from a kul origin, meaning that he was considered a slave of the sultan. Four out of seven grand viziers of Mehmed II were converted Christians with a kul background. ${ }^{65}$ This resulted in the fact that the grand vizier was completely dependent on the sultan. When looking at the end of these grand viziers lives, this dependency becomes obvious. Three out of the four grand viziers were executed while the fourth was banished into exile. ${ }^{66}$ Mahmud Pasha was also executed by the sultan, and before his execution he was dismissed two times. There are several reasons why Mahmud Pasha lost the trust of the sultan, including the hostility between Mahmud Pasha and the sultan's son Prince Mustafa, the advice of Mahmud Pasha to not follow Uzun Hassan after the battle of Otluk Beli, and the slander of Mahmud Pasha's rivals at court. ${ }^{67}$ It becomes obvious that Mahmud Pasha had no powerful family background at court which could have prevented his execution; he was completely dependent on the sultan's opinion and good will. Additionally, the sultan might have feared the increasing power of Mahmud Pasha and a collaboration with his enemies.

This might seem like a diminishment in power of a grand vizier, but on the contrary, the actual power and scope of action increased. Due to the new imperial image of the sultan, who increasingly withdrew from the public, the grand vizier became the deputy of the sultan and was in charge of all daily affairs at court. ${ }^{68}$ Right at the beginning of the kanunname the importance of this position is highlighted.

"Know that the Grand Vezir is, above all, the head of the vezirs and commanders. $\mathrm{He}$ is the greatest of all. He is the absolute deputy in all matters. The defterdar is deputy for my Treasury and he [the Grand Vezir] is the supervisor. In all meetings and in all ceremonies the Grand Vezir takes his place before all others." ${ }^{\prime 6}$ 
Stavrides calls Mahmud Pasha "a little Sultan in his own right"70 This expansion of power is not only visible in the theoretical status of the grand vizier, but Mahmud Pasha's life shows that he had indeed immense power and liberties which he used. He held two important military positions in his life, Beylerbey of Rumelia, which made him the commander of the Ottoman army in the Balkans and Sanjak-bey of Gelibolu, which made him the admiral of the Ottoman fleet. Mehmed II also centralised the army, which he did by diminishing the power of the military lords. Now Mahmud Pasha only had to answer to the sultan, which made this position more powerful than ever. ${ }^{71}$ After the conquest of Constantinople and the ongoing conflict with the naval power Venice, the need for a more powerful navy arose. The technical inferiority of the Ottoman's navy was compensated by the sheer amount of ships that were used. ${ }^{72}$ This strategy was also used in the battle of Negroponte in 1470, where a witness described the Ottoman fleet as a floating forest. $^{73}$

Mahmud Pasha also used his influence to establish two pious foundations and to construct various buildings. He built mosques, schools, madrasas and soup kitchens. Since 1204, Constantinople had begun to decline, and by the time of Mehmed II, the surrounding Ottoman cities such as Brusa or Adrianople were economically much stronger. Mehmed II was concerned about further damage a forceful conquest would cause. Eventually, he gave the order that looting the city would be allowed after a successful conquest, as entering the city more quickly was the main goal. This resulted in an even more damaged city, which had to be rebuilt by the Ottomans afterwards. ${ }^{74}$ Mahmud Pasha's architectural patronage contributed to the economic, social and cultural recovery of Istanbul. His mosques in particular became important religious centres around which whole complexes were built. ${ }^{75}$

The new empire did not only need new buildings, but also required a new literary tradition which would signify the importance of the empire. Mahmud Pasha was a literary patron as well as a poet himself. Similarly to the sultan's practice, he wrote poems in Turkish and Persian using a pen name. ${ }^{76}$ By writing in Turkish, Mahmud Pasha and the sultan contributed to the development of Ottoman-Turkish as a literary language. Translation works at the court aimed at the same goal. ${ }^{77}$ The frequent use of Persian words and the Persian language indicate that the sultan and his grand vizier tried to produce high-brow Ottoman literature, modelled after the great Iranian-Islamic empires of the past. ${ }^{78}$ Moreover, the sultan was also very much interested in European

70 Stavrides, The Sultan of Vezirs, p. 70.

71 Ibid., p. 192.

72 Ovidiu Christea, Venice Confronting the Ottoman Empire. A Struggle for Survival (Fourteenth-Sixteenth Centuries), in: Oliver Jens Schmitt (Ed.), The Ottoman Conquest of the Balkans. Interpretations and Research Debates, Vienna 2016, pp. 265-280, here p. 273.

73 Ibid., p. 275

74 Inalcık, The Policy of Mehmed II toward the Greek Population of Istanbul and the Byzantine Buildings of the City, in: Dumbarton Oaks Papers 23/24 (1969/70), pp. 229-249, here p. 231.

75 Stavrides, The Sultan of Vezirs, p. 287-288.

76 Ibid., Chapter 8.

77 Linda T. Darling, Political Literature and the Development of an Ottoman Imperial Culture in the Fifteenth Century, in: Journal of the Ottoman and Turkish Studies Association 1 (2014), No. 1-2, pp. 57-69, here p. 65

78 Stavrides, The Sultan of Vezirs, pp. 325-326. 
and especially Italian art and culture. Gentile Bellini, for example, was invited to the Ottoman court in 1479 and in 1480 produced a portrait of Mehmed II which remains the most well-known portrait of the sultan. ${ }^{79}$

\section{Conclusion}

In conclusion, Mahmud Pasha Angelovic served as a high official, vizier, and eventually grand vizier for more than twenty years. During these twenty years, the Ottoman state was transformed from a principality into an empire. The process culminated in 1453 with the fall of Constantinople and its renaming to Istanbul by Mehmed II. The fall of Constantinople marked the beginning of several new practices. Grand viziers now came mostly from a kul origin in contrast to the former ulama background. Mehmed II changed this practice to supress the old powerful families and enhance the dependency of the grand viziers. Shortly after the conquest, Mehmed II ordered the construction of a second new palace, which reflected the new imperial self-perception and led to a gradual withdrawal of the sultan from the public and eventually also from the divan. This conduct was sanctioned by Mehmed's new code of law: the kanunname, which also gave the centralised administration a clear hierarchy. Moreover, the kanunname describes the position of grand vizier as the deputy of the sultan. Even though the complete dependency seems to have limited the power of the grand vizier, in reality he had more power and more scope of action than ever before. This becomes visible in the person of Mahmud Pasha. He was responsible for many of the important conquests of that time, including the conquests in the Balkans. He facilitated the transition process in these new territories because of his family background of an aristocratic Balkan family. He also contributed to the religious, cultural, social and literary rise of the empire with his architectural and literary patronage. Despite his immense contributions to the empire, Mahmud Pascha's position fully depended on the sultan's goodwill. Lacking other allies, he was executed in 1474.

It can be said that Mahmud Pasha shaped the new centralised empire and is certainly one of the most important grand viziers of the Ottoman Empire. He, without a doubt, is the sultan of viziers.

\section{Sources}

Ibn Khaldun, The Muqaddimah. An Introduction to History, Princeton 1980.

Reinsch, Dieter Roderich, Mehmet II. erobert Konstantinopel. Das Geschichtswerk des Kritobulos von Imbros, Graz 1986.

79 Julian Raby, A Sultan of Paradox. Mehmed the Conqueror as a Patron of the Arts, in: Oxford Art Journal 5 (1982), No. 1, pp. 3-8, here p. 4. 


\section{Bibliography}

Afsaruddin, Asma, Ulama, in: Britannica, https://www.britannica.com/topic/ulama, accessed 30.11.2020.

Atçıl, Abdurrahman, Scholars and Sultans in the Early Modern Ottoman Empire, Cambridge 2016.

Babinger, Franz, Mehmed the Conqueror and his time, Princeton 1953.

Black, Antony, History of Islamic Political Thought, Edinburgh 2011.

Christea, Ovidiu, Venice Confronting the Ottoman Empire. A Struggle for Survival (Fourteenth-Sixteenth Centuries), in: Oliver Jens Schmitt (Ed.), The Ottoman Conquest of the Balkans. Interpretations and Research Debates, Vienna 2016, pp. 265-280.

Darling, Linda T., Political Literature and the Development of an Ottoman Imperial Culture in the Fifteenth Century, in: Journal of the Ottoman and Turkish Studies Association 1 (2014), No. 1-2, pp. 57-69.

Inalcık, Halil, The Policy of Mehmed II toward the Greek Population of Istanbul and the Byzantine Buildings of the City, in: Dumbarton Oaks Papers 23-24 (1969/70), pp. 229249.

Idem., The Ottoman Empire. The Classical Age 1300-1600, London 1973.

Isom-Verhaaren, Christine, Constructing Ottoman Identity in the Reigns of Mehmed II and Bayezid II, in: Journal of the Ottoman and Turkish Studies Association 1 (2014), No. 1-2, pp. 111-128.

Ivanovic, Milos, The Nobility of the Despotate of Serbia between Ottoman Empire and Hungary (1457-1459), in: Kosana Jovanovic/Suzana Miljan (Eds.), Secular Power and Sacral Authority in Medieval East-Central Europe, Amsterdam 2018, pp. 167-177.

Kadric, Sanja, The Islamisation of Ottoman Bosnia. Myths and Matters, in: Andrew C. S. Peacock (Ed.), Islamisation. Comparative Perspectives from History, Edinburgh 2017, pp. 277-295.

Krämer, Gudrun, Geschichte des Islams, München 2005.

Necipoğlu, Gülru, Architecture, Ceremonial, and Power. The Topkapi Palace in the Fifteenth and Sixteenth Centuries, Cambridge 1991.

Papoulia, Basilike D., Ursprung und Wesen der Knabenlese im osmanischen Reich, München 1963.

Raby, Julian, A Sultan of Paradox. Mehmed the Conqueror as a Patron of the Arts, in: Oxford Art Journal 5 (1982), No. 1, pp. 3-8.

Said, Edward, Orientalism. Western Conceptions of the Orient, London 1978.

Stavrides, Theoharis, The Sultan of Vezirs. The Life and Times of the Ottoman Grand Vezir Mahmud Pasha Angelovic (1453-1474), Leiden-Boston-Köln 2001. 
Tezkan, Baki, The Second Ottoman Empire. The Political and Social Transformation in the Early Modern World, Cambridge 2010.

Tworuschka, Monika, Grundwissen Islam, Münster 2016.

Wittek, Paul, Devshirme and Sharia, in: Bulletin of the School of Oriental and African Studies 17 (1955), No. 2, pp. 271-278.

Vera Flatz ist Masterstudentin im Masterstudiengang Lehramt für Sekundarstufe Englisch/Geschichte, Politische Bildung und Sozialkunde an der Universität Innsbruck. Vera.flatz@student.uibk.ac.at

\section{Zitation dieses Beitrages}

Vera Flatz, The Beginnings of an Empire. The Transformation of the Ottoman State into an Empire, demonstrated at the example of Grand Vizier Mahmud Pasha's life and accomplishments, in: historia.scribere 13 (2021), S. 257-271, [http://historia.scribere.at], eingesehen 22.6.2021 (=aktuelles Datum).

(C) Creative Commons Licences 3.0 Österreich unter Wahrung der Urheberrechte der Autorlnnen. 
